\title{
PUBLIC SPENDING AND ECONOMIC GROWTH PERFORMANCE: EVI- DENCE FROM NIGERIA
}

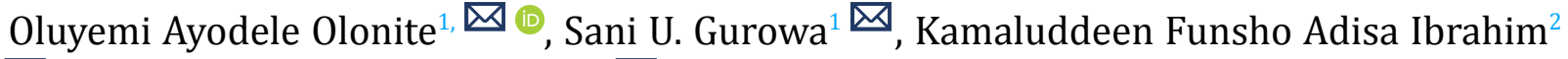

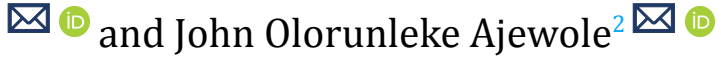 \\ ${ }^{1}$ Department of Accounting, Faculty of Management Sciences, University of Abuja, P.M.B 117, FCT-Abuja, Nigeria \\ ${ }^{2}$ Department of Accounting, Faculty of Management Sciences, University of Abuja, P.M.B 117, FCT-Abuja, Nigeria
}
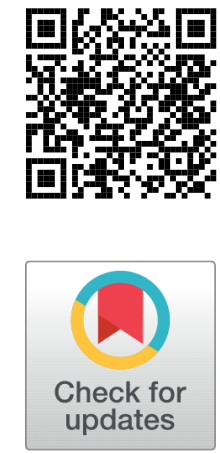

Received 15 June 2021

Accepted 1 July 2021

Published 31 July 2021

Corresponding Author

Oluyemi Ayodele Olonite, oluyemi

olonite@hotmail.com

DOI $10.29121 /$

granthaalayah.v9.i7.2021.4043

Funding: This research received no specific grant from any funding agency in the public, commercial, or not-for-profit sectors.

Copyright: (C) 2021 The Author(s). This is an open access article distributed under the terms of the Creative Commons Attribution License, which permits unrestricted use, distribution, and reproduction in any medium, provided the original author and source are credited.

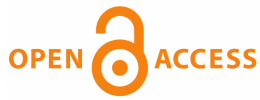

\section{ABSTRACT}

This study analysed the relationship between public spending and economic growth in Nigeria. The study used the secondary data from CBN 2018. The Real Gross Domestic Product formed the dependent variable and the independent variable of interest were the Capital Spending on Economic Services, and Spending of Transfers. The variables were validated by conducting the unit root test using the Augmented Dickey Fuller (ADF) and Phillips Perron Test (PP), and the correlation coefficient were determined using STATA and the Pearson Product Moment Correlation. A multiple regression model was employed for the study and was analysed using the Generalized Least Squares (GLSs) with the aid of Eviews 11 statistical program. The results of the study indicated that Capital Spending on Economic Services has a positive and significant impact on Economic Growth while Spending on Transfer has a negative and insignificant impact on Economic Growth. The study recommends that Capital Spending on Economic Services should be maintained and increased and Spending on Transfer should be made Zero, also, the government should develop the refineries to start mass production in order to null off the negative effect of transfers (subsidy payment on oil import and price equalization).

Keywords: Public Spending, Economic Growth, Capital Spending on Economic Services, Spending on Transfer, Nigeria, Central Bank of Nigeria, Statistical Bulletin

\section{INTRODUCTION}

Although the claim on the use of fiscal policy for economic stabilization and inducement of economic growth is seen to be old. It has become of interest to researchers and accountants in the field of Public Sector Accounting. Key issue in this debate relates to the efficiency of public spending in promoting economic growth.

Every nation's spending draws two sides spending, the capital and recurrent spending however, spending on transfers has been recognized as the third side of 
total spending. Spending on recurrent and Capital are governments' payments for non-repayable transactions within a year, governments' payments for non-financial (non-profit) assets used in the production for more than one year respectively and the latter, which is spending on transfers such as subventions. CBN (2018).

Public spending is a key instrument being employed by the government in controlling economic activities. The importance of public spending towards the functioning of any economy if developed, under developed or developing cannot be ignored. As seen by Okoro (2013), the need to allocate resources efficiently among the various arms of government, as structured by their fiscal ability, capacity and responsibility gave rise to Public Finance Management.

Economic growth is the increase in goods and services produced by an economy or nation, considered for a specific period of time. The rise in the country's output of goods and services is steady and constant and may be caused by an improvement in the quality of education, improvements in technology or in any way if there is a value addition in goods and services which is produced by every sector of the economy. It can be measured as a percentage increase in real gross domestic product and this means it has been adjusted for inflation. GDP is the market value of final goods \& services which is produced in an economy or nation (Government Spending Watch, 2019).

Economic growth, from the early period of economic history, engaged the attention of man and his governments. As far back as $17^{\text {th }}$ and $18^{\text {th }}$ centuries, writers like Adam Smith, David Ricardo, John Stuart Mill, as well as state theorist like Karl Marx, Friedrich List Karl Bucher, Rostow W. have all been preoccupied with the quest for unearthing the forces and processes that cause a change in the material progress of man. This is also applicable to successive governments and states in these modern times. In Nigeria for instance, the broad objective of the National Economic Policy has been the desire to promote sustainable economic growth for the vast majority of Nigerians through the adoption of the fiscal policies. Unfortunately, her economic growth performance has been characterized by fits and starts and the prospects of her rapid economic growth appear unachievable as reflected in her inability to realize sustainable full growth potentials and to significantly reduce the rate of poverty in the economy (Government Spending Watch, 2019).

Lack of public spending understanding by the majority of Nigerians and some government officials also resulted in problems for Nigeria. The Guardian News Paper in (2012), stated that the Federal Government restores transfer to fuel subsidy to quell the nationwide protests which claimed more than 10 lives and witnessed 600 Nigerians injured. Nigerians were angered on the basis that President Good luck Jonathan's Administration removed the payment of oil subsidy which hiked the prices of petrol across the county. It was argued by the President Jonathan's Administration that removing the transfer to oil subsidy which was estimated to cost $\$ 2,920,000,000,000$ (Two Trillion, Nine Hundred and Twenty Billion) per year would allow the government to spend money on needed public projects across Nigeria. This was also sup- 
ported by "BudgiT Civic Organization" (2019) that the opportunity cost of transfer to subsidy are: Build and Equip 2,400 units of 1,000-bed hospitals across 774 LGAs, or 500,000 New Houses for families through mortgage at $\$ 20,000,000$ per house, or Additional 27,000mega watts of solar powered electricity to the national grid, or Educate and Skill up 2,000,000 Nigerians with global standard quality tertiary education and sought-after skills. The broad objective of this study is to analyse effect of public spending on economic growth, gathering evidences from Nigeria. The specific objectives are: to examine the relationship between capital spending on economic services and economic growth, and to assess the relationship between spending on transfers and economic growth.

For the purpose of this study, the following hypotheses are stipulated in null form: There is no significant relationship between capital spending on economic services and economic growth, and there is no significant relationship between spending on transfers and economic growth.

The scope of this work is to analyse the nexus between public spending and economic growth using Nigeria as a case study and it is divided into five (5) sections, with this section being the introduction. Section two is about review of relevant literatures. Section three is on methodology of the research, while section four presents data, shows the analysis and discusses the findings. The fifth section concludes the paper.

\section{MATERIALS AND METHOD S}

\subsection{EMPIRICAL REVIEW}

The review of literatures of this study, focused on empirical and the theoretical perspectives. The basis of the study is to ascertain the role public spending plays in determining economic growth.

\subsubsection{EMPIRICAL REVIEW OF LITERATURE}

Analyzing the effect of public spending and taxes on economic growth in Spain and Armenia can be seen in the study of Sedrakyan and Candamio (2017) the sample size was between 1996 and 2014 using the Pedroni Cointegration and Granger Causality Tests. The result was that both the recurrent and capital spendings have a positive effect on economic growth. The study recommends increase in both recurrent and capital spending. This study is in consistent with the study of Bojanic (2013) but not in support of Loizides and Vamvoukas (2005) submissions who asserted that causality is seen from the economic growth to public spending.

In the study of Olugbenga and Owoye (2007) they investigated the relationships between public spending and economic growth in a group of thirty (30) OECD countries for the period covering 1970-2005 using the OLS Regression Analysis. Their analysis showed that there is a long-run relationship between public spendings and 
economic growth. The study also indicated a directional causality from public spending to economic growth for (sixteen) 16 countries. Their claim support the Keynesian hypothesis on this submission and Bojanic (2013). On the other hand, causality runs from economic growth to public spending in the remaining (fourteen) 14 countries in view, thereby disagreeing with the Keynesian hypothesis partially and agreeing with Loizides and Vamvoukas (2005) by asserting that causality can be from either the public spending to economic growth or vice-versa depending on the structure of the economy of the countries in view. They recommend that both the public spending and economic growth should be expanded. A study conducted by Kiraz and Gumus (2017) agrees with this finding.

Furthermore, Loizides and Vamvoukas (2005) used data set on three (3) countries (United Kingdom, Greece, and Ireland) from 1948 - 1995. They used the Cointegration Analysis, the ECM and the Granger Trivariate Causality Tests to examine the relationship between public spendings and economic growth. They concluded that the size of government spending causes economic growth in the three (3) countries. Such growth was experienced both in the long and short runs in the United Kingdom and the Ireland. Another inclusion into their model was by adding inflation which the result showed that economic growth granger causes government spending expansion in the United Kingdom and in Ireland. The study recommends more of government spending however, inflation can be seen as a tool for economy expansion. Their findings partly agree with the Keynesians hypothesis.

In their paper, Niloy et al. (2003) using a Panel Data Analysis to analyse the growth effects of disaggregated public spending (categories) in thirty(30) developing economies over the decades of 1970s and 1980s. The findings revealed that the percentage of public capital spending as a ratio of the Gross Domestic Products (GDP) is significantly and positively correlated with economic growth, in the other way round recurrent spending showed a negative correlation with economic growth. Furthermore, the findings at the functional level showed that public investment and total spending on education are the only outlays that remain significantly correlated with economic growth in the analysis. Their finding disagrees with that of Nwadiubu and Onuka (1980).

Kweka and Morrissey (1996) study on the effects of public spending on economic growth in Tanzania using a time series of Tanzania's economy from 1965 to 1996 by applying Ram (1986) model. The Ordinary Least Square was adopted for the Regression Analysis. Their findings asserted that increasing public spending strengthening economic growth in Tanzania. They thus recommend that the productive areas of public spending that drives growth should be a point of focus for the Tanzanian Government. Their submission is in line with the finding of Olugbenga and Owoye (2007), Olulu et al. (2014) but disagrees with the finding of Nwadiubu and Onuka (1980).

Looking at the paper Ebiringa and Charles-Anyaoku (2012) empirically, on the impact of government spending on economic growth in Nigeria focusing on 1977 
to 2011, they adopted the Error Correction Method (ECM) and the Cochrane-Orcutt Method to analyse the study variables, they found that spending on education sector, health sector, telecommunication, defense and security, had positive impact on Nigeria's economic growth while the spending on agriculture and transportation have negative impact on the economic growth of Nigeria. Their finding is in line with the submission of Bojanic (2013) but disagrees with the finding of Fan and Rao (2003).

The study on how the fiscal policies influences economic growth and development was carried out by Olopade and Olapade (2010) capturing the $1990-2004$ scope. The main reason conducting their study was to examine the components of government spending that increase growth and development in the economy and also to identify the public spending that do not have any significant impact on economic growth and development. The study adopted Statistical Methods capturing Simple Regression and Trends Analysis. Their finding revealed that there is no significant relationship between many of the components of public spending and economic growth. They however recommend that the spending that does not have positive impact on economic growth should be reduced to a reasonable minimum if need be or cut-off totally. Their findings correlates with the assertion of Akpan (2005).

In addition, Suleiman (2009) empirically observed the relationship between government spending, revenue and economic growth using the Panel Data Regression Analysis from 1978 - 2008. He asserted that the study will act as a fundamental step in knowing the behavior of the public spending in Nigeria and to obtain a gauge against which to analyse the stance of spending policy and total fiscal policy. His conclusion shows that growth in the real Gross Domestic Products (GDP) was significant prior to mid-1990s but fell substantially below the average public spending and revenue. He affirmed that, in the period of 1978 - 2008, government spending was not adopted as a fiscal tool and that the revenue growth was the function driving the public spending. He however recommends that the revenue base and scope should be increased and expanded since it drives positively public spending. His findings disagrees with the Keynesian hypothesis who found that causality runs from public spending to economic growth of a given country but partly agrees with Olugbenga and Owoye (2007).

Iheanacho (2016) study investigated the short and short run relationship between public spending and economic growth in Nigeria having the period of 1986 - 2014 in view. He used the Johansen Cointegration Tool to test for stationarity of the data employed before adopting the Error Correction Method (ECM). The result of his finding revealed that recurrent spending is the major driver of the Nigeria economic growth. Controlling for the influence of other revenue order than oil, his study revealed a negative and significant long run relationship between economic growth and recurrent spending coexists with a positive short run relationship, highlighting the dual effects of recurrent spending on Nigeria economic growth. As regards the capital spending, the author's documents negative and significant long run effect of capital spending on economic growth in Nigeria. Decomposition of the variance 
confirms the collective contribution of government spending on economic growth. He however recommends that public funds should be released on impactful projects rather than spending it on projects that will not grow the economy positively. His findings are in consistent with the submission of Oziengbe (1980), Bleaney et al. (2001) and Sedrakyan and Candamio (2017).

Available literatures have shown some empirical studies have been conducted on the impacts of public spending on economic growth. However, the findings of these studies have produced mixed and inconclusive results. Some of these studies have reported positive relationship or impact, while many others have found negative or no effects and spending of transfer has not been a major focus.

\subsubsection{THEORETICAL REVIEW}

Some basic theories have been used to support the impact of public spending on economic growth, they are: The Rostow-Musgrave Growth/Development Model and the Keynesian Hypothesis of Public Spending and Economic Growth.

Rostow-Musgrave Growth/Development Model (1969) provided a political theory of the role of public spending and the stages of growth in the process, and Musgrave (1969) presented a macroeconomic insight of public spending policy for development and industrialization. According to their model in early stages of economic growth and development, public sector investment is seen to be high. The public sector will in turn provide the human capital in the form of spending on health, education, etc. and social capital in the form of real (bridges, roads, transport, communication system technologies, and sea port). They argued that it is necessary for the spending in order to expand the economy towards the middle stages of economic growth and development. Based on the theories reviewed above, this study have adopted the Keynesian Hypothesis of Public Spending and Economic Growth since it is best suited for this study.

Keynes (1936) endorsed the influence of governments operations (spending) for many years on the economy claiming that it is important for governments to use public spending as an economic policy instrument (fiscal policy) to control the economy at the national level. In the Keynesian Hypothesis of Public Spending and Economic Growth public spending is seen as a policy instrument which can be used exogenously, because it is considered to impact economic growth and correct long-term and short-term cyclical imbalances. He asserted that Public spending is a cause which affect economic growth, thus the link for casualty can be seen from public spending to national income and not the other way round. In Keynesian hypothesis, demand can be treated as a foundation for growth. His analysis affirmed that economic performance may be improved by managing the demand policies.

The Keynesian theory and economic growth models in general, study public spendings as an element which affects economic growth in an economy. 


\subsection{METHODOLOGY}

The methodology of this study covers the research design (population and sampling techniques, measurement of variables, validation of research instrument and testing) and model specification.

\subsubsection{RESEARCH DESIGN}

The correlational research design (Ex Post Facto) was employed for this study. The adopted research design was used because it explores the relationship between variables using statistical analyses and mostly observational in terms of data collection. The population for this study is 39years observations (1981 - 2019). Based on the Purposeful Sampling Method, a sample of 15years observations (2004 - 2018) was used. The 2004 year scope was adopted since one of the variables (Spending on Transfer) reflected in 2004 as seen in the Central Bank of Nigeria Statistical Bulletin 2019 and the 2018 year scope was adopted since the available data stops in 2018. The independent variable "Capital Spending" was measured using the Capital Spending on Economic Services and Spending on Transfers was measured using the aggregate transfers while the dependent variable - "Economy Growth" was measured using the Real Gross Domestic Products (RGDP). The secondary data were validated using some testing tools before running the analysis. This tools tested their stationarity (Unit root test) using the Augmented Dickey Fuller (ADF) and Philips-Perron test (PP) to determine the level of integration of all the variables. All the variables were integrated at first order difference I(1). These tests were conducted to avoid generation of spurious regression results.

After reaching the correlation results between the variables, this study then

employed the Generalized Least Square (GLS) method to obtain the prediction coefficients of the Eviews 11.

\subsubsection{MODEL SPECIFICATION}

Economic Growth $=\mathrm{f}($ Public Spending)

$\mathrm{GDP}=\mathrm{f}($ Cspes, Stfs)

$\mathrm{GDP}_{t}=\alpha_{0}+\beta 1 \mathrm{cspes}_{t}+\beta 2 \mathrm{stfs}_{t}+\varepsilon_{t}$

Where: GDP = Gross Domestic Product (proxy for economic growth)

$\alpha_{0}=$ Coefficient of the constant variable

$\beta 1, \beta 2=$ Regression of the coefficient of the independent variable

Cspes $=$ Capital Spending on Economic Services

Stfs $=$ Spending on Transfers

$\varepsilon=$ the error term, which is also known as Epsilon.

$\mathrm{t}=$ at time $\mathrm{t}$ (annual time series)

The apriori expectations of the variables are given as $(\beta 1>0 ; \beta 2<0)$ i.e. cspes $>$ 0 , stfs $<0$. 


\section{RESULTS}

This chapter presents the result of the data analyzed and outlines findings of the study.

\subsection{DATA PRESENTATION}

\begin{tabular}{cccc}
\hline Table 1 Growth Data $2004-2018$ & & \\
\hline Year & $\begin{array}{c}\text { Real Gross Domestic } \\
\text { Product (RGDP) (\#' Billion) }\end{array}$ & $\begin{array}{c}\text { Capital Spending on } \\
\text { Economic Services (\#) } \\
\text { Billion) }\end{array}$ & $\begin{array}{c}\text { Spending on } \\
\text { Transfers (\#' } \\
\text { Billion) }\end{array}$ \\
$\mathbf{2 0 0 4}$ & 3311101.69 & 78.74 & 42.20 \\
$\mathbf{2 0 0 5}$ & 2454400.08 & 97.78 & 36.7 \\
$\mathbf{2 0 0 6}$ & 2520555.39 & -2.82 & 16.51 \\
$\mathbf{2 0 0 7}$ & 2926903.38 & 96.17 & 6.89 \\
\hline $\mathbf{2 0 0 8}$ & 3090107.38 & 145.91 & 60.27 \\
$\mathbf{2 0 0 9}$ & 3843583.77 & 2 & 9.65 \\
\hline $\mathbf{2 0 1 0}$ & 4756165.10 & -93.81 & 29.1 \\
\hline $\mathbf{2 0 1 1}$ & 2898777.59 & -25.8 & 277.68 \\
\hline $\mathbf{2 0 1 2}$ & 2418851.27 & -65.5 & -73.6 \\
\hline $\mathbf{2 0 1 3}$ & 3288828.69 & 184.87 & -17.53 \\
\hline $\mathbf{2 0 1 4}$ & 3934064.11 & 44.7 & -10.5 \\
\hline $\mathbf{2 0 1 5}$ & 1871144.10 & -44.7 & -38.82 \\
\hline $\mathbf{2 0 1 6}$ & -1092694.01 & -69.8 & 706.29 \\
\hline $\mathbf{2 0 1 7}$ & 559744.41 & 263.24 & -610.43 \\
\hline $\mathbf{2 0 1 8}$ & 1308961.61 & 211.3 & 22.05 \\
\hline
\end{tabular}

Data Source: CBN Statistical Bulletin, 2019

From Table 1 , it can be seen that the growth data for the real gross domestic product (rgdp) decreased in 2005 as against 2004 but increased consistently from 2006 to 2010, however, the rgdp decreased to (2898777.59) in 2011 from (4756165.10) in 2010 but rose to (3934064.11) in 2014 as against 2013 figure and furthermore increased to (1308961.61) in 2018.

The capital spending on economic services (cspes) data on the same table, which stood at 78.74 in 2004 rose to 97.78 in 2005 , however, the figures have seen to have fluctuated from 2006 through 2016. It increased to 263.24 in 2017 from \#69.8 in 2016 but later dropped to 211.3 in 2018 as against 2017 which has a value that stood at 263.24 this shows that spending on the economic services has not been increased substantially.

The spending on transfers (stfs) as seen in the same table shows that the growth increased and this has the highest percentage in compare to the capital spending on economic services as combined over the years which can be seen from $2004-2018$. It stood at 706.29 in 2018 due to the recession as the government injected money to service the subsidy payments. 


\begin{tabular}{cccc}
\hline \multicolumn{4}{c}{ Table 2 Summary of Descriptive Statistic } \\
\hline & RGDP & CSPES & STFS \\
\hline Mean & 55263521 & 400.3827 & 318.5880 \\
\hline Median & 57511042 & 386.4000 & 338.5500 \\
\hline Maximum & 69799942 & 753.4900 & 1044.840 \\
\hline Minimum & 35020549 & 167.7200 & 42.20000 \\
\hline Std. Dev. & 12519788 & 145.2277 & 252.3793 \\
\hline Skewness & -0.301088 & 0.727322 & 1.508077 \\
\hline Kurtosis & 1.604554 & 3.477527 & 5.555963 \\
\hline Jarque-Bera & 1.443678 & 1.465012 & 9.768829 \\
\hline Probability & 0.485858 & 0.480703 & 0.007564 \\
\hline Sum & $8.29 \mathrm{E}+08$ & 6005.740 & 4778.820 \\
\hline Sum Sq. Dev. & $2.19 \mathrm{E}+15$ & 295275.2 & 891734.1 \\
\hline Observations & 15 & 15 & 15 \\
\hline
\end{tabular}

Source: E-Views 11result, 2019

The skewness measures the asymmetric nature of the data; Skewness is a measure of the asymmetry of the probability distribution of a real-valued random variable about its mean. A normal distribution is symmetrical at point 0 . If the value is greater than zero ( $>0$ ) it's positively skewed, but if less than zero $(<0)$ it is negatively skewed according to Eviews (2019). Capital spending on economic services (CSPES) and spending on transfer (STFS) are positively skewed with the values 0.727322 and 1.508077 respectively while the real gross domestic product is negatively skewed with a value of -0.301088 .

Kurtosis measures the sharpness of the peak of a normal distribution curve. It is a measure of "tailedness" of the probability distribution of a real-valued random variable Eviews (2019). If the value is approximately equal to three, it is said to be mesokurtic distribution implying that it is a normal distribution. If approximately greater than three, it is leptokurtic distribution which has tails that asymptotically approach zero slowly and has more outliers than the normal distribution. While if approximately, less than three it is platykurtic which means that the distribution produces fewer and less outliers than the normal distribution; therefore (RGDP) showed evidence of platykurtic with values less than three; while the other variables (CSPES and STFS) showed a leptokurtic distribution with value greater than three. Given that two of the variables are not normally distributed, the Ordinary Least Square Method will not produce the accurate result because of the outliers instead Gurajati and Porter, (2009) suggested the Generalized Least Square Method as it will overcome the problem of outliers. 


\subsection{REGRESSION ANALYSIS}

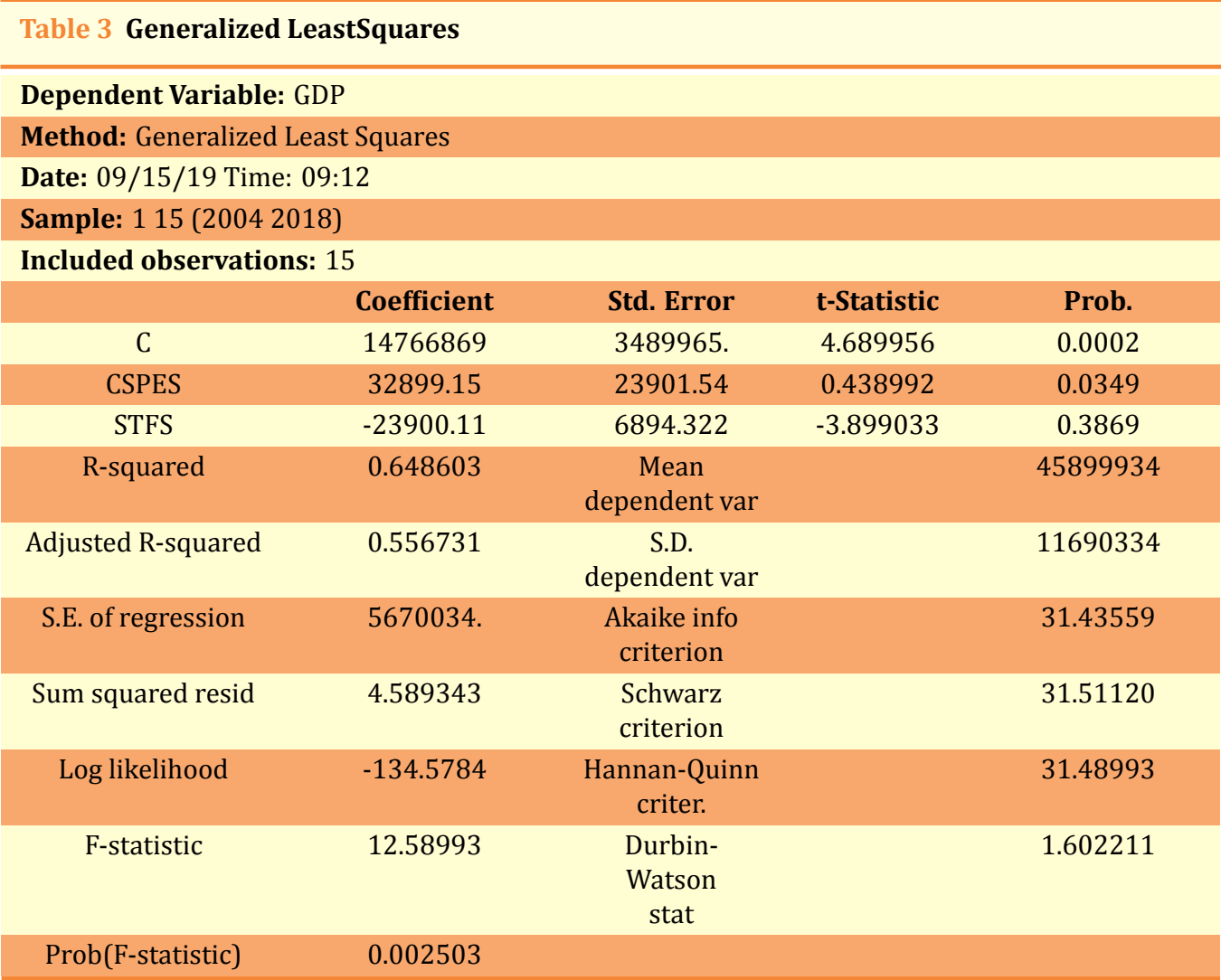

Source: E-Views 11 result, 2019

In Table 3 above, the Coefficient of CSPES is in line with the apriori expectations (CSPES > 0). CSPES has a positive coefficient of 32899.15 significant at $5 \%$ level which means that a percentage change (increase) in capital spending on economic services will increase the RGDP by $32899.15 \%$ positive unit change. The P-value is 0.0349 and since the P-value $(0.0349)<0.05$ (5\% level of significance), this study rejects the null hypothesis $1\left(\mathrm{H}_{0}\right)$ and conclude that the level of capital spending on economic services has significant on economic growth in Nigeria.

Also, STFS confirmed this study's apriori expectation, this study expects stfs to have a negative impact on the RGDP since it is seen as consumption spending of which subsidy payment is inclusive and as seen on the Table 3 , the coefficient is negative (-23900.11) and not significant which implies that when stfs increases by 1 unit, the RGDP also decreases by 23900.11 . The P-value is 0.3869 , and since the P-value $(0.3869)>0.05$ ( $5 \%$ level of significance), this study accepts the null hypothesis 3 $\left(\mathrm{H}_{0}\right)$ and conclude that spending on transfer does not have a significant relationship on economic growth in Nigeria.

The coefficient of determination as revealed by $R$-square $\left(R^{2}\right)$ indicates that $65 \%$ of the variations observed in the dependent variable (RGDP) were explained by com- 
bined influence and variations in the explanatory variables (CSPES and STFS) and the other $35 \%$ is attributed to other factors not included in the model.

The F-statistics which test the goodness of fit confirms that the model employed in the study is statistically significant given the value as 12.58993 , and the model is useful in explaining a unit change in Real Gross Domestic Product in Nigeria. On the whole, the overall probability (F-statistics) is 0.002503 significant at $5 \%$ i.e. $(0.002503<0.05)$.

The Durbin-Watson (DW) statistics is equal to 1.7; thus implying the absence of serial auto-correlation. This is because when the DW value is closer to two, it is an evidence of the absence of serial correlation.

\section{DISCUSSION}

The results indicate that Capital spending on Economic Services (CSPES) is positively related and have significant impact on Real Gross Domestic Product (RGDP). This study's result is consistent with the findings of Sedrakyan and Candamio (2017), Othman (2012) and Oziengbe (1980) but disagreed with Akpan (2005) who found an insignificant impact and a negative relationship between the Real Gross Domestic Product and Capital Spending on Economic Services; the Spending on Transfer (STFS) proves to be negatively related to RGDP being negatively signed and it is statistically insignificant in explaining the variation in Real Gross Domestic Product in Nigeria.

\section{CONCLUSIONS AND RECOMMENDATIONS}

\subsection{SUMMARY}

The results indicate that Capital Spending on Economic Services (CSPES) is positively related and have significant impact on Real Gross Domestic Product (RGDP) while Spending on Transfer (STFS) are negatively related and have insignificant impact on Real Gross Domestic Product. Testing of the three hypotheses of the research work, this study rejects null hypothesis (1) - $\mathrm{H}_{0}$ since it claims that there is no significant relationship between capital spending on economic services on economic growth whereas, the null hypothesis (2) - $\mathrm{H}_{0}$ was accepted which claims that there is no significant relationship between spending on transfer and economic growth. The estimation results reveal that the explanatory variables jointly account for approximately $65 \%$ percentage changes in economic growth as shown by the $\mathrm{R}^{2}$.

\subsection{CONCLUSION}

This work has so far explained the theories of government spending by relevant scholars such as the Keynesian Hypothesis of Public Spending (1936), the RostowMusgrave Growth/Development Model (1969) and the Public Finance Management Theory $(1919$ 
According to Keynes, he asserted that Public spending is a cause which affect economic growth, thus the link for casualty can be seen from public spending to economic growth and not the other way round.

The Rostow-Musgrave Growth/Development Model According to their model in early stages of economic growth and development, public sector investment is seen to be high. They argued that it is necessary for the spending in order to expand the economy towards the middle stages of economic growth and development.

\subsection{RECOMMENDATIONS}

Based on the findings of the result, the following actions are recommended

1. Capital spending on economic services should be increased since it was found to impact the real gross domestic product positively.

2. Since the analysis showed that spending on transfer have a negative impact on economic growth. Transfer spending should be made 0 most especially, on the non performing functions.

3. Since refinery is under the capital spending on economic services, it is highly recommended for the government to develop it for more production capacity and to null off the negative effect of transfers, most especially, on the non performing functions like the subsidy payment on oil import and price equalization.

\section{CONTRIBUTION TO KNOWLEDGE}

It seems as if concentration on the impact of government spending on transfer and economic growth in Nigeria have not been enough as many research studies have focused on the recurrent and capital spending and their respective disaggregated components, which can be seen in the studies of Sedrakyan and Candamio (2017), Othman (2012), Niloy et al. (2003), and Oziengbe (1980). Spending on transfer must not be swept under the rug because at the long run it will devastate an economy. In the case of Nigeria, with no strategic framework for the removal of the country's petrol subsidy program and a population expected to balloon to 398 million people by 2050, Nigeria risks carrying the financial burden of a subsidy program that could drown out development of its other sectors over the next 15 years. This study agrees partially with the Keynesian's theory of public finance and economic growth but disagrees because the Keynes (1936) did not capture spending on transfer as the model only fit into the economic situation of that time hence the theory has been weakened by "time" and "occurrences" In the light of this, this study developed a public spending and economic growth/development theory that fill all the gaps listed above. The theory is called "Olonite Theory of Public Finance and Economic Growth/Development of 2019".

Explaining Table 4 , public spending comprises of the recurrent expenditure, capital expenditure and expenditure on transfer. The recurrent expenditure and expen- 
diture on transfer won't drive economic growth since they are consumption expenditures. They won't drive economic growth; the capital expenditure is an investment spending which this study believes drives economic growth. In light of this, this study claim that recurrent expenditure should be kept minimal since it can't be equal to zero, as an increase in the capital expenditure will definitely expand the recurrent expenditure, though not in the same proportion. Some capital expenditure should be increased in particular, the performing functions while some functions decreased and this should be observed in respect to the public finance management theory by Erik Lindhal in 1919 and expenditure on transfer should be made to zero especially, the non performing functions since it has a negative impact on the economic growth. To reduce the recurrent expenditure and increase the capital spending, the Public Private Partnership (PPP) should be encouraged.

Table 4 Olonite Theory of Public Finance and Economic Growth / Development (2019)

\begin{tabular}{|c|c|c|}
\hline Version & Functions and Notations & $\begin{array}{l}\text { Valid } \\
\text { when }\end{array}$ \\
\hline \multirow[t]{6}{*}{$\begin{array}{l}\text { Olonite Theory of Public Finance and } \\
\text { Economic Growth/Development (2019) }\end{array}$} & $\begin{array}{l}\text { Gross Domestic Product }=\mathrm{f}(\text { Public } \\
\text { Spending) }\end{array}$ & \\
\hline & $\begin{array}{l}\text { Gross Domestic Product }=\mathrm{f}(\text { Recurrent } \\
\text { Expenditure, Capital Expenditure, } \\
\text { Transfer })\end{array}$ & $\beta>0$ \\
\hline & $\mathrm{GDP}_{t}=\alpha+\beta^{*} \mathrm{PS}_{t}^{\Theta, \downarrow, \downarrow, 0}+\varepsilon_{t}$ & \\
\hline & $\begin{array}{l}\mathrm{GDP}_{t} \rightarrow \uparrow=\alpha+\beta^{*}(\mathrm{REEXP}, \mathrm{CAEXP} \\
\mathrm{EXTRF}_{t}{ }_{t}^{\Theta, \downarrow, \downarrow}, 0+\varepsilon_{t}\end{array}$ & \\
\hline & $\begin{array}{l}\operatorname{GDP}_{t} \rightarrow \uparrow=\alpha+\beta^{*}\left(\operatorname{REEXP}^{\downarrow}\right. \\
\operatorname{CAEXP}^{\Theta(i a-o r-d-f s) \uparrow} \\
\left.\operatorname{EXTRF}^{0(i a-o r-d-f)}\right)_{t}+\varepsilon_{t}\end{array}$ & \\
\hline & $\begin{array}{l}\operatorname{GDP}_{t} \rightarrow \uparrow=\alpha+\beta^{*}\left(\operatorname{REEXP}^{\downarrow},\right. \\
\operatorname{CAEXP}^{\Theta(i a-o r-d-f s) \downarrow} \\
\left.\operatorname{EXTRF}^{0(i a-o r-d-f)}\right)_{t}+\varepsilon_{t}\end{array}$ & \\
\hline
\end{tabular}

Source: Author's Computation and Design 2019;

Notes: “ $\rightarrow \uparrow$ ” means: "to increase", “ $\downarrow$ ” means: "reduce”, “ $\downarrow$ ” means: "increase and reduce”, “0” means: "make zero". “ $\Theta$ ” means: "some”, PS denotes Public Spending, GDP means Gross Domestic Product, "i”" means non-performing, " $a-o r-d-f s^{\prime \prime}$ means aggregated or disaggregated functions.

\section{REFERENCES}

Akpan, N. I. (2005). Government Expenditure and Economic Growth in Nigeria: A Disaggregate Approach. CBN Economic and Financial Review, 43(1), 61-67.

Bleaney, M., Gemmell, N., \& Kneller, R. (2001). Testing the Endogenous Growth Model: Public Finance - A Disaggregated Analysis. Business and Economics Journal, 2(10), 1-11.

Bojanic, H. O. (2013). Government Expenditure and Economic Growth. A Panel Data Study. International Journal of Economics and Financial Issues, 4(13), 46-55.

BudgiT Civic Organization. (2019). Nigeria's Petrol Subsidy Regime: Dilemma of the World's Most Populous Black Nation. Budgit, 2-9.

CBN. (2018). Statistical Bulletin, Annual Report and Statement of Accounts, (Central Bank of 
Nigeria)., 125-320.

Ebiringa, O. T., \& Charles-Anyaoku, N. B. (2012). Impact of Government Sectorial Expenditure on the Economic Growth of Nigeria. International Journal of Economics Research, 3(6), $82-92$.

Eviews. (2019). Eviews 11 User's Guide.

Fan, S., \& Rao, N. (2003). Public Spending in Developing Countries: Trend, Determinants and Impact. EPTD Discussion Paper. IFPRI, 99, 118-176.

Iheanacho, E. (2016). The Contribution of Government Expenditure on Economic Growth of Nigeria Disaggregated Approach. In International Journal of Economics \& Management Sciences (Vol. 5, pp. 122-154). OMICS Publishing Group. Retrieved from https://dx.doi .org/10.4172/2162-6359.1000369 10.4172/2162-6359.1000369

Keynes, J. M. (1936). The General Theory of Employment, Interest and Money. The University of Adelaide Library.

Kiraz, H., \& Gumus, E. (2017). (Vol. 54).

Kweka, J. P., \& Morrissey, O. (1996).

Loizides, J., \& Vamvoukas, G. (2005). Government Expenditure and Economic Growth: London. Macmillan., 169-201.

Musgrave, R. A. (1969). Fiscal Systems. London. Yale University Press.

Niloy, B., Emranul, M. H., \& Osborn, D. (2003).

Nwadiubu, A., \& Onuka, I. O. (1980). Public Expenditure and Economic Development in Nigeria - A. Social Sciences Humanities, 1(5), 20-30.

Okoro, I. D. (2013). Effects of Public Expenditure on Economic Growth in Nigeria: A Disaggregated Time Series Analysis. International Journal of Management Sciences and Business Research, 1(7), 2226-8235.

Olopade, B. C., \& Olapade, D. O. (2010). The Impact Growth and Development in Developing Countries: Nigeria as a case study.

Olugbenga, A. O., \& Owoye, O. (2007). Public Expenditure and Economic Growth: New Evidence from OECD Countries. IAES, 222-356.

Olulu, R. M., Erhieyovwe, E. K., \& Andrew, U. (2014). Government Expenditures and Economic Growth: The Nigerian Experience. Mediterranean Journal of Social Sciences, 5(10), 8994. Retrieved from https://dx.doi.org/10.5901/mjss.2014.v5n10p89 10.5901/mjss .2014.v5n10p89

Othman, F. O. (2012). Impact of Government Expenditures on Economic Growth, Coventry University Press.

Oziengbe, S. A. (1980). The Relative Impacts of Federal Capital and Recurrent Expenditures on Nigeria's Economy. American Journal of Economics, 3(5), 210-221.

Sedrakyan, L. V., \& Candamio, G. S. (2017). The Impact of Public Expenditures on Economic Growth in Two Very Different Countries: A comparative Analysis of Armenia and Spain., 213-278.

Suleiman, A. S. (2009). Public Finances and Economic Growth in Nigeria: Fiscal Policy Implications in Crises Era. 